\title{
Acute and Subchronic Toxicities of Indonesian Mistletoes Dendrophthoe pentandra L. (Miq.) Ethanol Extract
}

\author{
Resmi Mustarichie*, Sohadi Warya, Nyi Mekar Saptarini, Ida Musfiroh \\ Department of Pharmaceuticl Analysis and Medicinal Chemistry, Faculty of Pharmacy, Univeristas Padjadjaran, Indonesia.
}

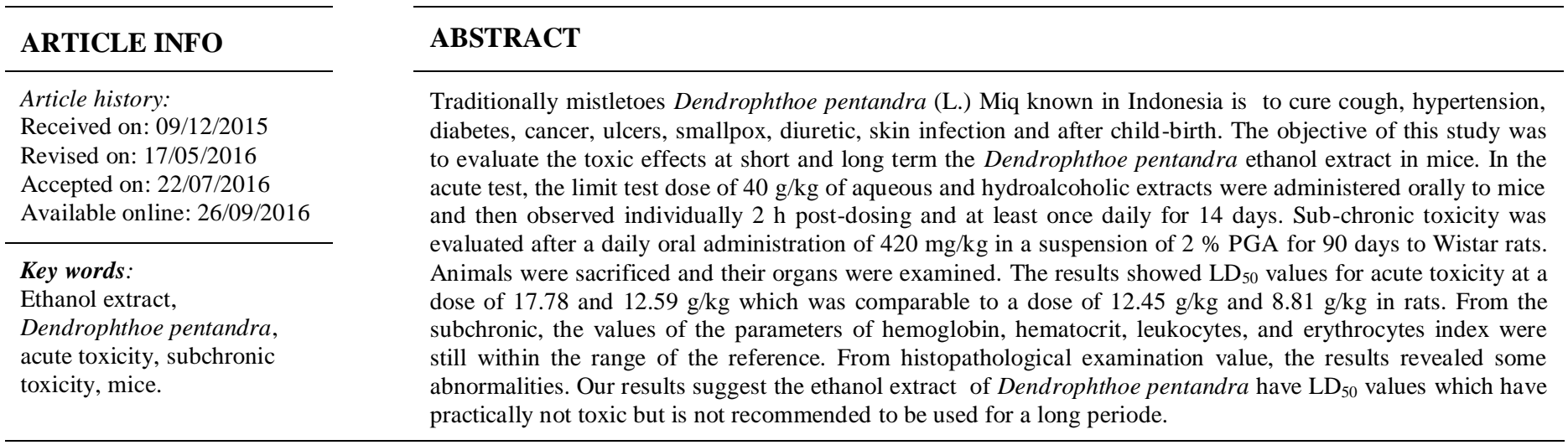

\section{INTRODUCTION}

Indonesia is known as a country with a great amount of plant biodiversity that is widely used as traditional medicines. One example of this traditional medicine is Dendrophthoe pentandra L. Miq. Traditionally, the mistletoe Dendrophthoe pentandra (L.) Miq is known in Indonesia to cure cough, hypertension, diabetes, cancer, ulcers, smallpox, , skin infection and for its therapeutic value after child-birth or as a diuretic. Mistletoe Dendrophthoe pentandra L. Miq. is sold in stores as a herbal tea and may be used to treat breast cancer,although it is actually a parasite of the mango tree (Hutapea, 1993; Dalimartha, 1999; Depkes RI. 2000). In Sulawesi, this plant is traditionally

\footnotetext{
* Corresponding Author

Resmi Mustarichie, Department of Pharmaceuticl Analysis and Medicinal Chemistry, Faculty of Pharmacy, Univeristas Padjadjaran, Indonesia.Email: rmustarichie @ yahoo.com
}

used as ananti-cancer agent (Ishizu et al., 2002; Zainuddin and Sul'ain, 2015). Katrin etal. (2005) her dissertation, claimed to isolate quercetin from mistletoe leaves Dendrophthoe pentandra (L.) Miq. Similarly, Artanti et al. (2006) isolated a flavonol glycoside, quercitrin (quercetin-3-O-rhamnoside) from star fruit (Averrhoa carambola) and mistletoe (Dendrophthoe pentandra (L.) Miq.). Quercetin fromplant extracts can be determined as the total alkaloid based on method of Chang et al. (2002).In vivo quercetin has been reported to have anti-inflammatory activity at a dose of $10 \mathrm{mg} / \mathrm{kg}$ body weight (Gusdinar et al., 2011). Quercetin content in Vitex trifolia L. was reported to have anti-inflammatory effect (Mustarichie et al., 2016).Quercetin isolated from leaf mistletoe has also been shown to inhibit L1210 leukemia cells (Katrin et al., 2011). Artanti et al. (2012) reported in vitro toxicity, antioxidant and antidiabetic activities of methanol and water extracts of $D$. pentandra. Fitrilia et al. (2015) reported regarding their phytochemical screening and reported on the antioxidant activity of clove mistletoe D. pentandra. 
We have previously reported ourstudy onthe interaction of quercetin and casticin with $\mathrm{H} 4 \mathrm{r}$, anti-inflammatory receptor, as supporting data for the anti-inflammatory herbal medicine Mustarichie et al., 2012, as well as on the total flavonoid content and anti-inflammatory properties of Indonesian mistletoe Dendrophthoe pentandra L. (Miq.) ethanol extract (Mustarichie et al., 2015). Wicaksono and Permana (2013) also stated Dendrophthoe pentandra potential as an anti-cancer agent colon.

In general, toxicity test methods can be divided into two groups (Loomis, 1978; Gossel and Bricker, 199; Lu, 1995). Acute toxicity tests are designed to determine the median lethal dose $\left(\mathrm{LD}_{50}\right)$ of a toxicant. $\mathrm{LD}_{50}$ is defined as the single dose of a substance that can kill $50 \%$ of test animals as described by Gossel and Bricker (1990). These types of tests quantify the acute toxicity of drug compounds, provide a therapeutic index (TI) or a safety limit for the particular drug compound, and provide an estimation of the therapeutic dose and initial dose of a drug study. The TIis an expression of the relationship between the therapeutic dose and the lethal dose and is calculated as the ratio of the $\mathrm{LD}_{50}$ to the $\mathrm{ED}_{50}$, i.e. $\left.\mathrm{TI}=\mathrm{LD}_{50} / \mathrm{ED}_{50}\right)$. Subchronic toxicity evaluations are used to determine the safety of use of a compound for a longer period of time (PPOM, 1991).

In this research, the acute and subchronic toxicity tests of Dendrophthoe pentandra ethanol extract in mice were carried out in order to obtain an overview of its safety margin for when it will be developed into a standardized herbal medicine.

\section{MATERIALS AND METHODS}

\section{Experimental animals}

Male and female mice (Mus musculus) weighing between 20-30 g and 2-3 months old, were obtained from the School of Pharmacy, Institute of Technology Bandung, Indonesia. Before use, the mice were acclimated for one week and their body weight was measured every day. Mice were said to be healthy if the weight increased or decreased by no morethan $10 \%$ of the previous weight with normal activity during the acclimation period. Ethical approval for this study was issued by the Kementerian Riset, Teknologi dan Pendidikan Tinggi, Fakultas Kedokteran Universitas Padjadjaran, Komisi Etik Penelitian Kesehatan No. 108/UN6.C.1.3.2/KEPK/PN/2015.

\section{Extraction method}

In order to ensure the sample (mistletoe Dendrophthoe pentandra) used was from the same source throughout the experiment, the fresh sample was collected in sufficient quantities $(\sim 10 \mathrm{~kg})$ at a time (Ahmad et al., 2009). The sample was collected from Subang area, West Java. First, the plant was washed thoroughly with running tap water, followed by rinsing with distilled water and then each part was cut into small pieces and powdered. They were sun dried $\left(\sim 30{ }^{\circ} \mathrm{C}\right)$ at open area with active ventilation until they attained constant weight (around three weeks). The Soxhlet apparatus was used for extraction process in which the extractor thimble was fitted in between a round bottom flask at the bottom and a bulb condenser at the top. Inside the thimble holder, $200 \mathrm{~g}$ dried Dendrophthoe pentandra powder was wrapped within a packing. Extraction using $1.8 \mathrm{~L}$ ethanol $75 \%$ was carried out till obtain clear droplets. This procedure was guided by Farmakope Herbal Indonesia (Departemen Kesehatan RI, 2015) and modified Gatbonton (2013) and Marnoto (2012) methods. The obtained extract was concentrated by using a rotary evaporator and freeze dryer.

\section{Test preparation}

The test preparation was made with a dose variation. Viscous extract was weighed according to the dose that had been determined and then prepared as asuspension using 2\%PGA, respectively preparations made as many as $10 \mathrm{~mL}$. Each of the test preparation was put into labeled vials.

\section{Acute and subchronic toxicity methods}

Acute and subchronic toxicity testing methods were based on modified Ouedraogo et al. method (2013). The OECD Guideline for Testing of Chemicals: 420 Acute Oral ToxicityFixed Dose Procedure (OECD, 2001) and The OECD Guideline for Testing of Chemicals: 408 Subchronic Oral Toxicity (OECD, 1998) as guidance for acute and subchronic tests, respectively. Toxicity studies of Pingale et al., (2011), Mridula et al. (2011) and Rais (2014) were also used as references to this study. Acute toxicity tests were conducted within 14 days, whereas subchronic toxicity tests were carried out for a period of 121 days. The subchronic toxicity tests used male and female white Wistar mice. Animals were grouped randomly into five groups of five mice each. The group given the test materials with different doses of a test group and a group of satellites, one group was given a liquid carrier as a negative group. Each test dose was administered orally for three months. The negative control group was given only the liquid vehicle. On day 91 of the experiment, the hematology and blood chemistry exams were conducted. Animals were sacrificed and their organs were examined and a histopathologic index was applied. The aim of this test was to determine the safety level for long-term use of the extract.

Data were analyzed statistically using analysis of variance design perfectly random. Observational data, such as the onset of toxic symptoms, were analyzed using the Friedman twoway analysis of variance for the acute toxicity test, whereas the subchronic toxicity data was analyzed using Student's t-test with a confidence level of $95 \%$ for the urine and blood parameters, blood biochemistry and organ indices. The parameters of body weight, gastric mucosal ulcer index and organ histopathology were conducted descriptively by direct observation of the presence or absence of change.

\section{RESULTS \&DISCUSSION}

\section{Extraction}

A viscous extract with a concentration of $13.28 \%$ was obtained by soxhletation of mistletoe Dendrophthoe pentandra 
using 95\% ethanol. The resulting extract was dark green in color, and had a distinctive smell and bitter taste. The water content of the ethanolic Dendrophthoe pentandraextract was $3.89 \%$. This value indicated that the ethanolic Dendrophthoe pentandra extract was of fairly good quality because the water content did not exceed the allowed moisture content standard of $\leq 4.1 \%$ (BPOM RI, 2004). That is, the extract could be stored for a long period of time without significant contamination by microbes or fungi.

\section{Acute Toxicity Testing}

The acute toxicity was evaluated through observation of mortality in mice over 14 days, observations of the weight of the mice for 14 days, and an observation ofthe mouse behavior for the first 24 hours after receiving the ethanolic extract of Dendrophthoe pentandra. The mortality data for the male and female mice is reported in Tables 1 and 2, respectively.

Table 1: Male mice mortality (\%).

\begin{tabular}{cccccccc}
\hline & \multicolumn{7}{c}{ Cumulative Mortality (\%) } \\
\cline { 2 - 8 } & $\mathbf{2}$ h & $\mathbf{4}$ h & $\mathbf{2 4 ~ h}$ & $\mathbf{4 8} \mathbf{h}$ & $\mathbf{7 2}$ & $\mathbf{7} \mathbf{~ d}$ & $\begin{array}{c}\mathbf{1 4} \\
\mathbf{~ h}\end{array}$ \\
\hline Control & 0 & 0 & 0 & 0 & 0 & 0 & 0 \\
Dose I (5 g/kg BW) & 0 & 0 & 10 & 10 & 10 & 10 & 10 \\
Dose II (10 g/kg BW) & 0 & 0 & 20 & 20 & 20 & 20 & 20 \\
Dose III (20 g/kg BW) & 20 & 40 & 40 & 40 & 40 & 40 & 40 \\
Dose IV (40 g/kg BW) & 40 & 50 & 70 & 70 & 70 & 70 & 70 \\
Dose V (80 g/kg BW) & 90 & 90 & 90 & 90 & 90 & 90 & 90 \\
\hline
\end{tabular}

Table 2: Female mice mortality (\%).

\begin{tabular}{|c|c|c|c|c|c|c|c|}
\hline \multirow[b]{2}{*}{ Mice } & \multicolumn{7}{|c|}{ CumulativeMortality (\%) } \\
\hline & $2 \mathrm{~h}$ & $4 \mathrm{~h}$ & $24 \mathrm{~h}$ & $48 \mathrm{~h}$ & $\begin{array}{l}72 \\
\text { h }\end{array}$ & $7 \mathrm{~d}$ & $\begin{array}{c}14 \\
\text { d }\end{array}$ \\
\hline Control & 0 & 0 & 0 & 0 & 0 & 0 & 0 \\
\hline Dose I ( 5 g/kg BW) & 0 & 0 & 0 & 0 & 0 & 10 & 10 \\
\hline Dose II $(10 \mathrm{~g} / \mathrm{kg} \mathrm{BW}$ & 0 & 0 & 40 & 40 & 40 & 40 & 40 \\
\hline Dose III (20 g/kg BW) & 10 & 10 & 40 & 50 & 50 & 50 & 50 \\
\hline Dose IV (40 g/kg BW) & 50 & 80 & 80 & 80 & 80 & 80 & 80 \\
\hline Dose V (80 g/kg BW) & 90 & 90 & 90 & 90 & 90 & 90 & 90 \\
\hline
\end{tabular}

To calculate the value of $\mathrm{LD}_{50}$, results of toxicity test data was drawn to a straight line between log dose vs probit percentage value. Probit percentage determined using probit table (Finney and Stevens, 1948) by changing the value of $\%$ of animal deaths to the percentage in the table probit. Having obtained a linear line equation, then the $\mathrm{LD}_{50}$ was calculated by changing the value of y to 5 , the results obtained made his anti-Log (Kobayashi and and Pillai, 2013; Hayes and Dipasquale, 2001) as shown in Figure 1.

Curve of blue line shows the cumulative mortality (\%) of male mice over the 14 day period, compared with that of the females (red line). Based on the Figure 1, it was found male and female mice had $\mathrm{LD}_{50}$ of 17.78 and $12.59 \mathrm{~g} / \mathrm{kg} \mathrm{BW}$, respectively. By extrapolation, a dose of $17.78 \mathrm{~g} / \mathrm{kg}$ in mice was comparable to a dose of $12.45 \mathrm{~g} / \mathrm{kg}$ and $12.59 \mathrm{~g} / \mathrm{kg}$ was comparable to $8.81 \mathrm{~g} / \mathrm{kg}$ in rats. According to the criteria of Hodge and Sterner (Table 3), the results of toxicology $\mathrm{LD}_{50}$ value has meaning and it could be concluded that the ethanol extract pentandra Dendrophthoe pentandra in the range of doses was practically not toxic as $\mathrm{LD}_{50}$ is the dose range of 5-15 g/kg BW rat. These results were consistent with the results obtained by Katrin et al. (2005a), who found that up until a dose of $2000 \mathrm{mg} / \mathrm{kg}$ body weight of animal died and was no significantly toxic effects.

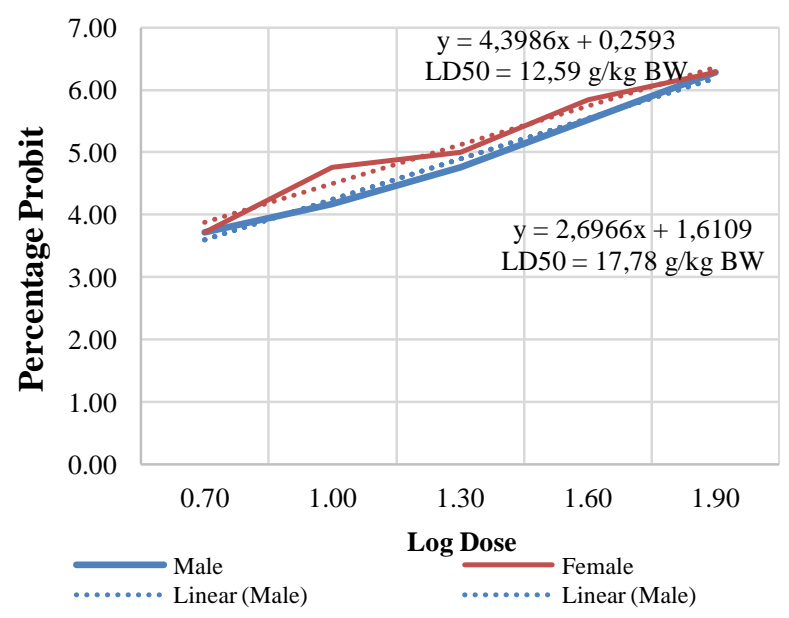

Fig. 1: Log Probit Analysis of Dendrophthoe pentandra.

$\mathrm{LD}_{50}$ of groups of males and females show different values. This is consistent with the theory put forward by Lazarovici and Haya (2002) which states that between males and females there are differences in sensitivity to a toxicant. The differences are influenced directly by the endocrine glands, therefore it can be said the gender differences affect the value of $\mathrm{LD}_{50}$.

Table 3: A substance toxicity Assessment.

\begin{tabular}{lll}
\hline Toxicity levels & General terms & LD $_{50}$ in rats (orally) \\
\hline 1 & Unusually toxic & $\leq 1 \mathrm{mg} / \mathrm{kg}$ \\
2 & Very toxic & $1-50 \mathrm{mg} / \mathrm{kg}$ \\
3 & Quite toxic & $50-500 \mathrm{mg} / \mathrm{kg}$ \\
4 & Slightly toxic & $0,5-5 \mathrm{~g} / \mathrm{kg}$ \\
5 & Practically non-toxic & $5-15 \mathrm{~g} / \mathrm{kg}$ \\
6 & Relatively safe & $>15 \mathrm{gkg}$ \\
\hline (Derelanko, 2008). & &
\end{tabular}

\section{Observations on Body Weight}

Daily body weight was observed for 14 days in both the male and female mice. This was conducted to determine if the extract had any effect on weight for the two week period following administration. These data were analyzed using analysis of variance (ANOVA). The results ofthe statistical testing demonstrated that there was no significant difference in body weight of the male and female mice as a result of the administration of different doses of the extract at a significance level of 0.05 .

\section{Subchronic toxicity testing}

White Wistar rats were divided into three groups of five animals: a control group, a test group, and the group of satellites. Each group received their test preparation orally, once a day for 90 days. The control group was given the vehicle, a suspension of $2 \%$ PGA, and the satellite test group was given the ethanolic extract of Dendrophthoe pentandra at a dose of $420 \mathrm{mg} / \mathrm{kg}$ in a suspension of $2 \%$ PGA. 


\section{Changes in Body Weight}

No significant differences were observed in body weight following the administration of the Dendrophthoe pentandra ethanol extract test preparation at a dose of $420 \mathrm{mg} / \mathrm{kg}$ as compared with the satellite animals and the controls, that received vehicle only (Tables 4 and 5).

\section{Blood Biochemical Examination Results}

The blood biochemical tests are a very important aspect of the toxicology tests, and they are essential to understand the mechanisms of the disease process, specifically regarding the enzyme levels in the liver and kidneys.

\section{A. Liver Function Test}

The results of the liver function tests in mice are presented below (Table 6). SGOT and SGPT values were statistically different between the groups $(0.018, p<0.05)$. Data showed that the SGOT values were greater in the test group than in the control group, but the value was still approaching the reference value. The results of SGPT levels in the test group were smaller than the control group, but the overall value of SGPT was much larger than the reference value, indicating liver damage.

\section{B. Kindey Function Test}

The results of the kidney function test in mice are shown in Table7 below.

\section{Animal Blood Test Parameters}

The results of the blood panel are shown in Table 8. A blood panel, consisting of the parameters hemoglobin, hematocrit, leukocytes, erythocytes, thombocytes, and erythrocytes index (MCV, MCH, and MCHC) was carried out. Statistical analysis revealed no difference between groups for hemoglobin, hematocrit, leukocytes, and index erythocytes (MCV, MCH, and MCHC) because the value sig $(0.018<0.05)$. The values of the parameters of hemoglobin, hematocrit, leukocytes, and index erythrocytes were still within the range of the reference value, whereas the erythrocyte and platelet values for all groups, especially the test group and satellite group were well above the reference values. This was expected because the entry of foreign substances triggers the body's response with regard to bleeding and tissue damage.

Table 4: Rat body weight.

\begin{tabular}{|c|c|c|c|c|c|c|c|c|c|c|c|c|c|}
\hline Group & H7 & H14 & H21 & H28 & H35 & H42 & H49 & H56 & H63 & H70 & H77 & H84 & H91 \\
\hline Test & 236.39 & 241.14 & 238.57 & 243.29 & 243.32 & 243.89 & 246.04 & 244.71 & 246.61 & 248.25 & 250.00 & 244.07 & 210.11 \\
\hline Control & 243.54 & 244.00 & 246.64 & 250.68 & 250.04 & 248.89 & 251.68 & 251.54 & 252.14 & 252.00 & 248.46 & 243.36 & 209.32 \\
\hline
\end{tabular}

Notes: $\mathrm{H}=$ Testing times (days)

Table 5: Change inanimal weight

\begin{tabular}{|c|c|c|c|c|c|c|c|c|c|c|c|c|}
\hline Group & H7 & H14 & H21 & H28 & H35 & H42 & H49 & H56 & H63 & H70 & H77 & H84 \\
\hline Test & 4.75 & -2.57 & 4.71 & 0.04 & 0.57 & 2.14 & -1.32 & 1.89 & 1.64 & 1.75 & -5.93 & -33.96 \\
\hline Control & 0.46 & 2.64 & 4.04 & -0.64 & -1.14 & 2.79 & -0.14 & 0.61 & -0.14 & -3.54 & -5.11 & -34.04 \\
\hline Satellite & 4.11 & 4.14 & 5.96 & -0.14 & 1.71 & 3.43 & 2.89 & 5.61 & 0.54 & 4.39 & -1.50 & -34.93 \\
\hline
\end{tabular}

Notes: $\mathrm{H}=$ Testing times (days)

Table 6: Liver Enzymes: SGOT and SGPT Levels

\begin{tabular}{|c|c|c|c|c|c|c|}
\hline Group & SGOT (IU/L) & Value Reference & Value SIG & SGPT (IU/L) & Value Reference & Value SIG \\
\hline Test & 148 & 141 & 0.018 & 57 & 12.6 & 0.018 \\
\hline Control & 114 & 141 & 0.018 & 61 & 12.6 & 0.018 \\
\hline Satellite & 134 & 141 & 0.018 & 66 & 12.6 & 0.018 \\
\hline
\end{tabular}

Table 7: Creatinine Levels.

\begin{tabular}{|c|c|c|c|}
\hline Group & Creatinine (mg/dl) & Reference Value & $p$-value \\
\hline Test & 0.25 & $0.2 \sim 0.8 \mathrm{mg} / \mathrm{dL}$ & 0.018 \\
\hline Control & 0.27 & $0.2 \sim 0.8 \mathrm{mg} / \mathrm{dL}$ & 0.018 \\
\hline Satellite & 0.28 & $0.2 \sim 0.8 \mathrm{mg} / \mathrm{dL}$ & 0.018 \\
\hline
\end{tabular}

Creatinine levels were significantly different among all groups $(p<0.05)$.However, creatinine values of all groups are still within the range of the reference value.

Table 8: Animal Blood Test Results

\begin{tabular}{|c|c|c|c|c|c|}
\hline \multirow{2}{*}{ Blood Parameter } & \multicolumn{5}{|c|}{ Group } \\
\hline & Test & Control & Satellite & Reference value & SIG value \\
\hline Hemoglobin (g/dL) & 14.2 & 13.2 & 14.3 & $11.5 \sim 16.1$ & 0.018 \\
\hline Hematocrit (\%) & 45 & 40 & 45 & $36 \sim 52$ & 0.018 \\
\hline Leucocytes $\left(/ \mathrm{mm}^{3}\right)$ & 3,300 & 3,000 & 3,100 & & 0.018 \\
\hline Erythocytes (mil/uL) & 7.83 & 6.91 & 7.86 & & 0.018 \\
\hline Thombocytes $\left(\mathrm{mm}^{3}\right)$ & $1,112,000$ & 870,000 & $1,251,000$ & $150,000 \sim 450,000$ & 0.018 \\
\hline MCV (fL) & 57.5 & 57.9 & 57.5 & $48 \sim 70$ & 0.018 \\
\hline $\mathrm{MCH}(\mathrm{pg})$ & 18.1 & 19.1 & 18.2 & $17 \sim 21$ & 0.018 \\
\hline $\mathrm{MCHC}(\%)$ & 31.6 & 33 & 31.6 & $35 \sim 43$ & 0.018 \\
\hline
\end{tabular}




\section{Histopathological Examination Results}

The histopathological examination results are shown in Table 9.

Table 9: Resultsof histopathological examination

\begin{tabular}{|c|c|}
\hline Organ & Histological analysis \\
\hline Liver & $\begin{array}{l}\text { U: necrosisof hepatocytes }(++) \text {, vacuolization }(++) \text {, hydropic } \\
\text { degeneration }(+++) \text {, inflammation }(++) \text {, bleeding }(++) \\
\text { K: necrosis of hepatocytes }(+) \text {, vacuolization }(+) \text {, hydropic } \\
\text { degeneration }(+) \text {, inflammation }(+) \\
\text { S: necrosis of hepatocytes }(+) \text {, vacuolization }(++) \text {, hydropic } \\
\text { degeneration }(++) \text {, inflammation }(+) \text {, bleeding }(+)\end{array}$ \\
\hline Kidney & $\begin{array}{l}\text { U: Acute Tubular Necrosis (NTA) }(+++) \text {, vacuolization and } \\
\text { degeneration of the proximal convoluted tubule and distal } \\
\text { convoluted tubules }(+++) \text {, bleeding }(++) \\
\text { K: vacuolization and degeneration of the proximal convoluted } \\
\text { tubule and distal convoluted tubules }(+) \text {, bleeding }(+) \\
\text { S: Acute Tubular Necrosis (NTA) }(++) \text {, vacuolization and } \\
\text { degeneration of the proximal convoluted tubule and distal } \\
\text { convoluted tubules }(++) \text {, bleeding }(+)\end{array}$ \\
\hline Heart & $\begin{array}{l}\text { U: Bleeding (++), inflammation (+) } \\
\text { K: Bleeding }(+) \\
\text { S: Bleeding }(+) \text {, inflammation }(+)\end{array}$ \\
\hline Tumors & $\begin{array}{l}\text { U: Lymphoma (+++) } \\
\text { S: still visible remnants of connective tissue and inflammation }\end{array}$ \\
\hline \multicolumn{2}{|c|}{$\begin{array}{l}\text { Notes: } \quad+=\text { Slightly damaged } \\
++=\text { Moderate damage level } \\
+++=\text { Heavy damage level } \\
\mathrm{U}=\text { Group test } \\
\mathrm{K}=\text { Control group } \\
\mathrm{S}=\text { Satellite group }\end{array}$} \\
\hline
\end{tabular}

The histopathological examination of test animals included an examination of the heart, liver, kidney, and tumors. In the most severe case, kidney damage found in the test groups, which manifested as acute tubular necrosis, vacuolization and degeneration of the proximal convoluted tubule and distal convoluted tubules, as well as massive bleeding. In the group of satellites, A cute Tubular Necrosis, vacuolization and degeneration of proximal and distal convoluted tubules lighter than thetest group. However, more severe than in the control group in which the control group was very mild abnormalities in the kidneys.

Histopathological examination of the liver showed hepatocytenecrosis, vacuolization, hydropic degeneration, inflammation, and severe bleeding. In the satellite group, the observed hepatocytenecrosis, vacuolization, hydropic degeneration, inflammation, and bleeding was not as severe as in the group test, but it was worse than in the control group. In the heart, bleeding and severe inflammation were present in the test group as compared with the control group and satellite group. From the observation Satelliteand Test group found any swelling suspected tumor. In the test group shown Lymphomas evere, and in the group of satellites was able to seethe rest of the connective tissue and inflammation. These tumors could be associated with a given dose of the extract, because they the control group, did not happen the same as in the other two groups were given the extract.

\section{CONCLUSION}

Acute toxicology testing revealed that the ethanolic extract of the herb Dendrophthoe pentandra had a $\mathrm{LD}_{50}$ of 17.78 and $12.59 \mathrm{~g} / \mathrm{kg}$ which was comparable to a dose of 12.45 and 8.81 $\mathrm{g} / \mathrm{kg}$ in rats. Based on the toxicity classification of Hodge and Sterner, it can be concluded that the ethanol extract of the herb Dendrophthoe pentandra can be categorized as practically nontoxic, but long term use is not recommended.

\section{Financial support and sponsorship: Nil. \\ Conflicts of interest: There are no conflicts of interest.}

\section{REFERENCES}

Ahmad A, Abbas FM, Hena S, Khim LH. Extraction, Separation and Identification of Chemical Ingredients of Elephantopus Scaber L. Using Factorial Design of Experiment, International Journal of Chemistry, 2009; 1 (1): 36-49.

Artanti N, Firmansyah $\mathrm{T}$ and Darmawan A. Bioactivities evaluation of Indonesian mistletoes, (Dendrophthoe pentandra (L.) Miq.) leaves extracts, J App Pharm Sci,2012; 02 (01): 24-27.

Artanti N, Ma`arifa $\mathrm{Y}$ and Hanafi $\mathrm{M}$. Isolation and identification of active antioxidant compound from star fruit (Averrhoa carambola) mistletoe (Dendrophthoe pentandra (L.) Miq.) ethanol extract. J App Sci, 2006; 6: 1659-1663.

BPOM RI. 2004. Monografi Ekstrak Tumbuhan Obat Indonesia. Volume I. Jakarta: BPOM RI, 83-84.

Chang CC, Yang MH, Wen HM, Chern JC. Estimation of total flavonoid content in propolis by two complementary colorimetric methods. J Food Drug Anal, 2002; 10: 178-182.

Dalimartha S, 1999. Atlas Tumbuhan Obat Indonesia. Jilid I. Jakarta: PT Pustaka Pembangunan Swadaya, 120-121.

Departemen Kesehtaan RI, 2015. Farmakope Herbal Indonesia, Edisi I, Jakarta, 17-18.

Depkes RI. 2000. Inventaris Tanaman Obat Indonesia. Jilid I. Jakarta: Badan Penelitian dan Pengembangan Kesehatan RI, 29-30.

Derelanko, MJ, 2008. The Toxicologist's Pocket Handbook. Second Edition. New York: Informa Healthcare USA, Inc.,193.

Finney DJ. and Stevens WL. A table for the calculation of working probits and weights in probit analysis." Biometrika , 1948; 35 (12): 191-201.

Fitrilia T, Bintang M, Safithi M. Phytochemical screening and antioxidant activity of clove mistletoe leaf extracts (Dendrophthoe pentandra (L.) Miq). IOSR J Pharm, 2015; 5 (8): 13-18.

Gatbonton GL, De Jesus APP, Lorenzo KML and Uy MM. Soxhlet extraction of Philippine avocadro fruit pulp variety 240, Presented at the Research Congress 2013 De La Salle University Manila March 7-9.

Gossel TA and Bricker JD, 1990. Principles of Clinical Toxicology. New York: Raven. 4-5, 27.

Gusdinar T, Herowati R, Kartasasmita RE and Adnyana. Antiinflammatory and antioxidantactivity of quercetin-3,3',4'-triacetate, Journal of Pharmacology and Toxicology, 2011; 6 (2): 182-188.

Hayes W and Dipasquale L, 2001. Principle and Methods of Toxicology. London: The Gillette Company, 853-873.

Hutapea J, 1993. Inventarisasi Tanaman Obat Indonesia, Departemen Kesehatan R.I.

Ishizu T, Winarno $\mathrm{H}$, Tsujino $\mathrm{E}$, Morita $\mathrm{T}$, Shibuya $\mathrm{H}$. Indonesian medicinal plants. XXIV Stereochemical structure of perseitol $\mathrm{K} 1$ complex isolated from the leaves of Scurrula fusca (Loranthaceae). Chemical Pharmacology, 2002; 50 (4): 489-492.

Katrin WE, Tambunan RM, dan Winarno H. Uji aktivitas inhibisi isolat quersitin dari benalu marsisin Dendrophthoe pentandra ( (L) Miq.) terhadap sel leukimia L1210.Jurnal Ilmu Kefarmasian Indonesia, 2011; April, 1-7.

Katrin, Andreanus A. Soemardji AA, Soeganda AG, Soediro I. 2005.,. Aktivitas Imunostimulan Beberapa Tumbuhan Obat Indonesia serta Isolasi dan Identifikasi Senyawa Imunostimulan Daun Dendrophthoe pentandra (L.) Miq. Dessertation, ITB, Indonesia. Available at http://bahan-alam.fa.itb.ac.id (Accessedon January 19, 2015) 
Katrin, Andreanus A. Soemardji AA, Soeganda AG, Soediro I. The acute toxicity of isolates from n-hexane and ethanolic fraction of Dendrophthoe pentandra (L.) Miq. which have immunostimulatory activity, Majalah Farmasi Indonesia, 2005; 16 (4): 227-231.

Kobayashi K and Pillai KS, 2013. A Handbook of Applied Statistics in Phrmacology, CRC Press, USA, 156-158.

Lazarovici Pand Haya L, 2002. Chimeric Toxin: Mechanisms of Actions And Theraupeutic Applications. Taylor dan Francis Group.

LuFC, 1995. Toksikologi Dasar. Edisi II. Penerjemah: Edi Nugroho. Jakarta: UI Press. From Lu's Basic Toxicology - CRC Press, 66-67, 70-73, 86.

Marnoto T, Haryono G, Gustinah D, Putra FA. Ekstraksi tannin sebagai bahan pewarna alamai dari tanaman putri malu (Mimosa pudica) menggunakan pelarut organic, Reaktor, 2012; 14 (1): 39-45.

Mridula M, Shikha G, Abid M, Ghosh AK. Toxicity study of alcoholic extract of the aerial parts of Aristolochia indica L., IJRAP, 2011; $2(5): 1560-1562$.

Mustarichie R, Levita $\mathrm{J}$ and Saptarini NM. The study of the interaction of quercetin and casticin with $\mathrm{H} 4 \mathrm{r}$, anti-inflammatory receptor, as supporting data for anti-inflammatory herbal medicine.Journal of Computer Science, Technology and Application, 2012; 1 (1) : 70-76.

Mustarichie R, Wardhana YW and Wahyudi R. Antiinflammation of Tablet Legundi (Vitex trifolia L.) Ethanol Extract With Variation of Sodium Starch Glycolate, Int.J.Res.Ayurveda Pharm, IJRAP, 2016;7 (1):114-117.

Mustarichie R, Warya S, Saptarini NM and Ramdhani D, 2015.Total Flavonoid Content and Anti-Inflammatory Properties Of Indonesian Mistletoes (Dendrophthoe pentandra L. (Miq.) Ethanol Extract., World Journal of Pharmaceutical Research , WJPR, 2015; 4 (4): 287-302.

Organization of Economic Co-operation and Development (OECD), -Rodent: 90-Day Study, OECD, Paris, France, 1998.

Organization of Economic Co-operation and Development (OECD), The OECD Guideline for Testing of Chemicals: 420 Acute Oral Toxicity-Fixed Dose Procedure, OECD, Paris, France, 2001.

Ouedraogo GG, Ouedraogo M, Lamien-Sanou A, Lompo M, M. Goumbri-Lompo OM and Guissou PI. Acute and Subchronic Toxicity Studies of Roots Barks Extracts of Calotropis procera (Ait.) R. Br Used in the Treatment of Sickle Cell Disease in Burkina Faso, British Journal of Pharmacology and Toxicology, 2013; 4 (5): 194-200.
Pingale SS. Acute toxicity study for Tinospora cordifolia, IJRAP, 2011; 2 (5):1571-1573

PressLoomis TA, 1978. Essentials of toxicology, 3rd ed., Philadelphia: Lea and Febiger, 23, 258.

Pusat Pemeriksaan Obat dan Makanan (PPOM). 1991. Prosedur OperasionalBaku Uji Toksisitas. Depkes RI. Jakarta, 4-63.

Rais IR. Andrographolide extraction from Andrographis paniculata (Burm.f.) Nees using soxhlet extractor, Pharmaçiana, 2014; 4 (1): 85-92.

Wicaksono MHB and Permana S. Potensi Fraksi Etanol Benalu Manga (Dendrohthoe petandra) sebagai Agen Anti Kanker Kolon pada Mencit (Mus musculus Balb/c) setelah Induksi Dextran Sulvat (DSS) dan Azoxymethane (AOM). J Biotropika, 2013;1 (2): 75-79.

Zainuddin NASN and Sul'ain MD. Phytochemical analysis, toxicity and cytotoxicity evaluation of Dendrophthoe pentandra leaves extracts, International Journal of Applied Biology and Pharmaceutical Technology, IJABPT, 2015;108-116.

\section{How to cite this article:}

Mustarichie R, Warya S, Saptarini NM, Musfiroh I. Acute and Subchronic Toxicities of Indonesian Mistletoes (Dendrophthoe pentandra L. (Miq.) Ethanol Extract. J App Pharm Sci, 2016; 6 (09): 109-114. 